\title{
A Study of Denizen Thought of Empire and Place of Indians as Subhuman in Foster's India; Neo Oriental Approach in the Eyes of Edward Said
}

\author{
Muhammad Ehsan \\ PhM Scholar, Department of English Language \\ \& Literature, The University of Lahore, Pakistan \\ ehsanlitterateur@gmail.com
}

\author{
Atta-ul-Mustafa \\ Assistant Professor of English, Department of \\ Humanities and Linguistics, University of \\ Agriculture, Faisalabad. Pakistan
}

\section{Sahar Zeeshan}

Lecturer in English, Department of English Language \& Literature, The University of Lahore Pakistan

\begin{abstract}
The delegacy of the settled acculturations and the social orders by the advocates of colonialism has been an area under discussion of colossal grandness, both to truster and postcolonial detractors and authors. The colonialist discourses and pennings incline to contrive the Denizens and the Denizen mores as prescriptive measures. The occupied diversity is demoed as be a short of or freakishness. The Brit authors and disparager fed on the Orientalist discussions, have been contriving their own heritage and acculturation as higher, and presenting the Indians as inferior. E.M. Forster has limned the colonialist mythos of the eminence of Caucasian and its way of life and the erected lowliness of India and the Indians in "A Passage to India". This bailiwick aimed to scrutinize the op of the colonialist dogma in "A Passage to India", to indicate that Forster destined to strengthen the colonialist thought of transcendency, with the illustration of India and people of India as pigeonholes and marginalised natives and society in his "A Passage to India". The bailiwick also sought to inspect the nexus 'tween culture and imperialism and the concomitant apery and hybridism amidst the Indian people and the exploitation of the distinctiveness of the Indian people. This research was founded on the scrutinize of the text of the novel under the view of Postcolonial theories. The work detected that novel akin to any colonial discourse favored the Colonizers and the European conventions and philosophies while the Indian people and their mores were portrayed as toerag and lower stamps.
\end{abstract}

Keywords: Colonialism, Denizens, Orientalist discussions, A Passage to India, Edward Said.

\section{INTRODUCTION}

Edward Said (1993) justifiedly argues to litai cannot be politically clean-handed. Martin Green (1980) also grasps akin views on the subject of literature. The lunge of this bailiwick is to provide evidence that "A Passage to India" is laded with colonialist thought of highness and shows Subcontinent, people of Subcontinent and culture of India as poorer, substandard and low-grade. This study anchored au fait the rigorous scrutiny of "A Passage to India" in the light of postcolonial theory, it shows that the Brit functionaries in Subcontinent e'er weighed and dealt Indian people as pigeonholes. This paper has uncovered colonizers' intrinsic tendencies and narrow-mindedness headed for the Indian people. The study has also spotlighted the wallop of the settler thought and mores upon the local customs and uniqueness.

Forster limns the Orientalized India and damns clichéd depiction of the Indian people. The characters of his novel are the dupes of European regal power and exploitation. From another point of view, Foster picks apart the Indian people's passiveness against the progression of orientalization. Furthermore, this research indicates how Forster tags on the pigeonholes the Brit colonizers assigned to the Indians.

As a result, there egresses the polemic of case-by-case flair and colonial folklore as invented by T.S. Eliot in his "Tradition and Individual Talent" (1919) and enforced to the arena of colonial discourse by Edward said in "Orientalism" (1978) and its continuation "Culture and Imperialism" (1993). 
The aim of this paper is to analyze that Foster as envoy writer of the Brit colonial practice and mull over his piece of writing as an essential part of the lit that waged in the course of prop up for the Brit imperium with a hub on their personage talents and arty individualities. Approximating factual, Foster's novel is no elision in respect to the depiction of the oreintals as lower to the Denizens. The India and the Indians are considered as substandard to the Britishers, who confer on their selves with a sort of burthen, carrying glow, culture and civilisation for the Asians, an errand that is putatively acquitted for the support of realm. Like Kipling, Foster's novels stay behind close to the fixed vision of the Indian people. Consequently, Indians are classified with diverse stamps that are all associated to "retardation" and "content", two features that can be elucidated at diverse stages.

\section{LITERATURE REVIEW}

Earmarking Foucault's concept of discourse, Said (1995) avers that "Orientalism expresses and represens culturally and even ideologically as a mode of discourse with supoorting institions". The discourse of Oreintalism rivets a British mode for prevailing, reconstituting, reformation, rectification and having influence over the eastern hemisphere. The Brit colonial ritual and the personage flair fall into the sort of inquiry on postcolonial studies, its body is colonial writing, but the judgmental point of view is postcolonial (Kennedy 2000).

E.M.Forster spotlights the progression of initializing, which the newbies have to undergo so that they fetch up like the other colonists in stipulations of their mythos and praxises. It is pointed out that Foster's "A Passage to India" assays to raft with colonialism or post colonialism or neo colonialism with reverence to the vitriolic wallop on individual kinships induced by the chauvinistic suppositions and psychiatry intrinsic in regal imperialism (Brandabur 1993). To Jan Mohamed, Foster's " $A$ Passage to India" sets about "To overcome the barriers of racial difference" (Childs 1999, p.348). On the other hand Nirad Chaudhuri criticized it "For its reduction of political history to a liberal's preoccupation with personal relationships" (Childs, p.347).

Preceding erudite writings such as Chrles Allen (2009), Ali Behdad (1994), Purabi Panwar (2000), Teresa Hubbel (1996), Benita Parry (2004), Patrich Brantlinger (2013) and Avron Fleishman (1967) have identified each of the four writers Rudyard Kipling, Edward Morgan Foster, William Somerset Maugham and Joseph Conrad within the skeleton of the Western colonial practice.

The previous thrives in the vicinity of colonial discourse that expanded in the $19^{\text {th }}$ and near the beginning $20^{\text {th }}$ century to legit the regal influence. In colonial discourse, writers are hired in dianoetic performs with other writers and the chronological instant in which they socialize their writings and they are queried by the thought of realm. It was reenforced by the thoughts of other postcolonial sages like Bhabha, who developed his premise about colonial discourse in the emplacement of acculturation (2004), assuming as a beginning stage, various notions adopted from Said's theory of Orientalism (kennedy, 2000). In "A Passage to India" the colonizers are emphatically the solider people and have bureaux over the natives. They are awarded power by this right which they apply against the Indian Nation as inferior race (Boehmer 1995). Penelope Pether (1991) has examined Foster's "A Passage to India” primarily from the biographic point of view, at the same time as Brenda R. Silver (1991) has looked at the work of fiction from the libber viewpoint. Benita Parry (1985) has traced the issue of colonialist and imperialistic delegacy of local people. Sara Suleri (2005) has looked at the novel from a sexual orientation viewpoint and its expression in "A Passage to India". But they have omitted lots of serious issues in the research that should to be talked to. Some critics that have talked about did not examine the novel from the viewpoint of the demonstration of Indian people, even as some critics have not amply focussed their notice on the illustration of Indian Subcontinent and Indian people as stereotypes and inferiors by Forster. Richard Cronin (1998) has committed a phase of research to " $A$ Passage to India" but has not riveted upon the depiction of the Indian people as inferior created by Forster. Ralph J. Crane (1992) inclines that Forster's "A Passage to India" evades politics. Actually, the novel treats with the political affairs, once more from the outlook of the realm. Crane fails to find out the passivity of Indian politics and Indians as inferior nation. The above given succinct review of literature not only gives the framework for the present research, it gives good reason for its need as well. The present research aims to attempt a new analysis of the novel in the light of postcolonial theory.

\section{RESEARCH METHODOLOGY}

The current study is based upon the exhaustive analysis of "A Passage to India" in the light of postcolonial critical theories. The major proposition of this study is that Forster has represented India 
and Indians from the colonialist perspective and has used the stereotypes constructed by Western Orientalists about Indians to contain them and to perpetuate the empire, and to establish the superiority of the British and the inferiority of the Indians. The study intends to prove that Forster is a colonialist writer, who has written from the colonialist perspective of superiority and the novel is a colonialist representation of India.

Having an eye on Said's postcolonial theories, the current work spotlights on the hackneyed illustration of the Indian people and the consequences of such inferiority of the Indians on producing two illusory uniqueness for them that compel the Indian people to practice a twofold containment. Additionally, it assists the development of colonization that is vindicated as the outcome of substandard features amid the locals with the explanation of fulfilling humanizing and educating missions. Using such stereotypes and stamps which are imposed on the European mind are the results of imperialist generalization. The main proposal of this paper is to highlight that Forster has represent the superiority of the Europe and the inferiority of the India and the Indians. It also spotlights the imperialistic thought of transcendency in "A Passage to India."

\section{DiscusSiOn AND ANALYSiS}

\subsection{Low-Grade Colonized India and Indians as Subhuman}

The aperture episode of the novel "A Passage to India" educates the reader towards the delineation of Subcontinent and people of India as less important, low-grade, poorer and substandard. Chandrapore, an imaginary town of India, the ambiance, the scenery and the people of Chandrapore are showed as disparaging and mortifying. It shows the colonialist thought of the writer, who considers the colonized land and the colonized people as second-rate and have no fellow feeling for Indians. The narrative has no feelings of compassion. The Ganges River wedges junk without stinting in the environs of the town Chandrapore. Every thing is ineffective even temples and streets in the town only a few houses are shown fine but all of them blotted out by the scuzz of the alleyways. The town is bereft from art and paintings. We are come to know by the anecdotist that all of colonized India is humiliated and humdrum. The station city of colonizers is completely different from the local towns and cities.

Forster expresses egotism in the personage and in the social order as a depraved historical force as Conrad did in his Heart of Darkness and his character Kurtz's final utterance: "The horror! The horror?"

"The colonial situation manufactures colonialists, just as it manufactures the colonized" (Memmi 1974). Britishers, the experient settlers, wedge their own stamps of the locals upon newbies. The colonizers disembark freshly from their motherland "intending to be gentlemen, and are told it will not do." Thence, "they all become exactly the same - not worse, not better" (p.34). Ronny Heaslop quetches that "people are so odd out here, and it's not like home - one's always facing the footlights .... They notice everything, until they're perfectly sure you're their sort" (p.68).

Astoundingly, Crane (1992) arrogates that Forster has unwrapped the novel with the most benevolent figures. He irrationally exacts that Forster in "A Passage to India" intentionally eases up an optimistic notion of the Indian people. We can say, it is a very grievous misconception of the book. Forster's portraiture of the Indian people is from the colonialist point of view, synecdochical and subtractive. Forster says nothing about the celebrated hospitality of the East. The hookah (nargileh) passes the odor like cow muck, as Indian bazaars do. At the house of Hamidullah, the Indians are presented like strivers. The anecdotist affirms the matter and the diminishing position of the people of Indian. Forster, in lieu of empathetically elucidating assesses, traditions and customs of India, fêting the fortitude of forfeit and fidelity for the ménage that exposed by the Indian fair sex, points out the fortune of Indian women not as good as men. The wifey of Hamidullah is in purdah (veil). She deems that Indian women have no doable animation and survival devoid of wedlock with male. The anecdotist delimits the fortune of the Indian fair sex as attach with men.

The Indian people are presented as fainéant with parasitical dispositions. Latif is exposed vexing about philosophic and political consequences. This is an off-putting remark on the Indians. The Indian people are revealed possessed with the times of yore, their deceased vastitude. Major Callender is in the wont of debasing and demeaning. Dr. Aziz is depicted only as a picayune Indian. The land of India is nasty. It is erratic, defective, perfidious, punic and unfaithful. The entrance of the Moslem place of worship is spifflicated; its patio is covered with kaput blocks. The Indian people are 
portrayed as distress from the wont of amplification. Dr. Aziz is showed as a distinctive Asian, as made-up by Westerly Specializers, a mime gentleman's gentleman. He conceives that his societal bond with European White Men can construct him an everlasting valet, as manoeuvered by Fanon (2008). The Indian people are not permitted into Chandrapore club without doing their apery and absolute adaptation of majestic colonial way of life. According to the dissimilar scrutiny of Singh (1975), Forster in "A Passage to India" is a propagandist, who is diffusing the Brit philosophy of preeminence and dominancy. The comments of an Ex-British Nurse, "the kindest thing one can do to a native is to let him die" shows the British cruelty towards Indian people. The Bridge Party is arranged by Turton to amuse Miss Quested. Turtons represent The Raj and their status in India is "little gods". Ronny's picture of the Indian people is subtractive as hashed out by Said, a reiteration of Orientalist twist of pigeonhole. Said peculiarly adverts to this facet of Ronny. Said delineates the Brit functionaries in the vein of Ronny as a vernal English young man shipped to India whose national ascendance was downright, over Indian people.

The storyteller in Foster's work "A Passage to India" casts India as an aeonian hobo camp overran with dirty dogs, flutters, hymenopters and Canisaureuses without any secernment of home or woods. The Indian people are pictured as very dying to attend the party arranged by Turton. The delegate of the Raj Ronny, the vernal English young man is pregnant of distrust for the Indian invitees at the party. He gives his sagacity on the native invitees at the party as, "seditious at heart". He indicates the apery among the Indian people, an undeviating outcome of political orientation. Said (1993) and Fanon (2008) have indorsed this feature of political orientation in a meticulous mode. The Indian people have mimed the etiquettes, the modus vivendi and the clothing code to the level that Ronny does not consider them as the Indians. They blink their specs, European style shoes and attires. Mrs. Turton is tempestuous that natives are countenanced in the club. For Mrs. Turton says that Urdu Language is merely a cant, the terminology of minor community. It is only a typecast picture, entailed to buttress the colonial philosophy of pre-eminence and to comprise the India and the local people. Mrs. Bhattacharya is introduced as a half-wit kid, doesn't know what she is talking on. Mr. Turton the emcee of the bridge party draws the Indians in the most subtractive line of attack, "when they had not cheated, it was bhang, women, or worse, and the desirables wanted to get some thing out of him". This is what is named the twist of the Orient by the Occidental narratives as hashed out by Said. Cronin sanctioned the aforesaid, who asseverates that his India lived for him still ere he saw it in 1920. His Subcontinent was thrown to him and drew in "A Passage to India" by Forster (1989). India is an abject state, for Ronny that seized by force. He is adjudicating justness while fenced by falsehood, mendacity and sycophancy. On the other hand, Mrs. Moor, who likes Fielding, is an emblematic manifestation of the current disputation about how the settlements are to be reigned cues Ronny that God has sent them as a superior royal class in the world to civilize and govern the people around them.

Forster presents the Indians are as a race who look for or forge grudge. Dr. Aziz is presented as degustation his despondency. The biracial discrimination of the European against Locals would not abscond them still at the sports grounds and race would put forth its toxicant where ever feasible. The Indian people are limned as groveling towards the Colonizer and breathing with incessant trepidation. Dr. PanaLal has crawling terror for his malfunction to pay heed the greeting from the Colonizer Accumulator. The Indian people even the well-informed ones are depicted as anxious to gratify their Denizen lords. Despite the apery and faux on the part of skilled Indians, they are not yet admitted as robust and appropriate to banquet at an White man's table. The White Men are expressed peculiarly detesting the Indian natives with mod thoughts. Said screams this approach on the part of Occident as reflection of ethical supremacy.

As a community, Indians are staged by the colonialist writer E. M. Forster who doesn't heed about their allegiances and fealties. Mr. Heaslop gives his assessment against the natives. Hindoos are described as limp, nighted and with no concept of hygiene. Said adverts to the use of this typecast by Foster for the Hindoos in the colonial narratives, "The Hindoo is innately mendacious and misses ethical audacity".

The Indian people are presented as sheepish of themselves with their mores and traditions. The native culture and identity are reflected by the impact of imperial culture. Dr. Aziz is also pictured as mortified of his ménage, which he reckons as a hutch. It is overrun with disastrous flies. Dr. Aziz is pictured as a man, who has imbibed the European ethnicity to the phase that he has arisen an Orientalist hallucination, heading to hedonism and self-disgust. Dr. Aziz is called as a mimic man, in 
other words, the bemused Occidentalized type by Ronny. Ronny treats the Indian people in rudely manner and calls them as untamed animals. He also calls Dr. Aziz as a "bounder", someone who is morally reprehensible. All of these are the examples of the creation of the stamps to portray the Indian people as substandard and their common use for the local Indian people with the purpose to continue the European traditions and imperium.

\subsection{Contrast between the Colonizer and the Colonized}

In Forster's A Passage to India, the land of India is showed as hapless even trees are showed in a meager value. The White people are introduced as tranquil at the crisis time, at the same time as the Indian people are presented jabbering about helplessly. Colonized India is pictured as an instance of raison d'être and neatness, while the Indian Subcontinent is absurd, cockeyed and irrational. The prevaricator draws the painting of Indian people as neutral to ethics and personage liability, on the other hand the White race painted as royal and immortal. Indian people seem substandard and rough through their minds. Dr. Aziz, a sophisticated Indian man but he showed too ugly person who don't care of cleaning his dwelling, like Gandhi does in R.K. Narayan's novel (2000). His fellows are depicted as poor quality citizens.

It is showed by Forster that learned and cultured Indian people like Dr. Aziz would keep away from political affairs at any cost. This is what the imperium sought after and empire always creates as people who don't speak against their imperial policies as Dr. Aziz did. Forster also desired to promote the political propaganda of the Colonial British Empire. Fielding gives his opinion, "England holds India for her good", the replication of the creation of Kipling, "White man's burden". Dr. Aziz, Haq, and others accept their meagerness and lowliness at every step. This is enough to vindicate the existence of the European in Subcontinent evermore and evermore. The whole thing connected to India is awful and hideous even April is showed a month of revulsions. Indian sun, rather than having any splendor and brilliance is baleful.

The tykes India are revealed like imps. The Indian people are showed as pestiferous, dreadful people, associated with smell. Their deficiency of decorum is horrible. The sketch is satirically summarized as, "the celebrated Oriental confusion". The British Raj functionaries always portray Indian people as inept of liability. The Indian chef is revealed making tea in the toilet. Mrs. Moor passes her remark, "a strange place to make tea."

The hot and dry weather of India is never forgotten; Foster criticized it in abrasive manner. In May, fire is fallen on Indian land and on the sea by the Indian sun. On the other hand the English poets and novelists make merry the loveliness of their scenery here, the storyteller keens that India is the motherland of "fields, fields, then hills, jungle, hills and more fields". In the eyes of Forster, India is not a hope but only a pleading, circuitously vindicating the British Raj. The Moghul inheritance in the form of curtilages, places of worship, garrisons and edifices are called "Moghul Derisory", things have no meaning and importance. The sunup of India brings only letdown, stoppage and frustration nothing else. New morning gives no hope, vision and miracle. The sun of India gets up with no any grandeur. India is only a hideous, stodgy and unventilated site. The Indian sun is perfidious, April scatters covetousness like pestilence. The splendor of the aurora is only related to the White people. Tho' Gandhi (Narayan, 2000) adjudges the flowing streams of India as good-looking and retrieves the sunup beset with colorings and the zephyr so brisk. The land of India is the dirtiest portrayed by Forster's India. Zulfiqar Ghose, a Pakistani litterateur in foreword to "The Murder of Aziz" proclaims the landscape of India is the loveliest landscape on the planet of the human race. At the picnic occasion, the attack of an elephant on local villagers and au naturel babies showed the unlatched life of the native people. The portrayal of au naturel babies describes the Indian savageness and also the Indians necessitate any civilized authority that can make them good and cultured because they don't maintain their lives without royal domain. It is another attempt for the construction of the Orientalists. The Oriental fool Dr. Aziz, not adequate to see the divergence between cordial reception and relationship. The portrayal of Mrs. Moor, as a considerate image, and is considered by some evaluators as benevolent for India and native people but in fact is modern assimilatory colonial approach to carry on the imperium. Through the trope of echo, Indian Subcontinent is presented as a torso which misses unfairness and perspicacity. Aziz acquits like a tyke in the face of the Raj functionaries. Only Fielding, a man who can domesticate him. Fielding is represented as a miraculous person who has the grip over everything and can control everything. The Indian people mewl and 
bawl at this adversity, including Dr. Aziz. McBryde, the Western policeman, has an Orientalist ism about the natives. According to him, all Indians are criminals in one way or another way. McBryde tells to Fielding, the mental behavior of the people is dissimilar in India. It is declared by the accumulator, India is a "poisonous country" and its natives as Canis aureus.

Approximately all the White characters have faith in the kookiness, retardation and passive plasticity of the Indian people. Colonized land is pictured as a place marooned from the majority of British development in the sciences, arts and trade. Godbole, though, immersed in Hindoo mythos and Indian philosophy but not free from the sway of colonial traditions and the ensuant apery. He gives the name to his school on the name of King George IV. The Indian people are called as niggers (dark skinned creature). McBryde arises with yet another dissertation on Oriental autoimmunity, "The darker races are physically attracted by the fairer, but not the vice versa". Fowzia Afzal (1993) justly delineates McBryde's position as a protraction of a philosophy of control. The counselor Muhammad Ali, is pictured as a distinctive Indian. He is presented as an unfledged and infantile man who deports in a majorly absurd manner during the tryout.

It is illustrated by McBryde as the innate motion of 'a substandard race'. The Indian people are depicted as a group of people, whose no cultural values and norms. Orientals are presented opting delirium and the communal flaunt of feelings. The storyteller iterates the axiom of that keen advocate of Imperium, Kipling as said by George Orwell and cited by Said (1993). They created stories that are completely far away from veracity and verity. Every Indian is a snoop and is beatified with the profligate vision, another European creation of the Orient. The thwarting of cause and sort, a clutter is showed as the 'impending coup of India'.

\subsection{Neo-Assimilative Approach of Political Orientation and Imperialism}

The picture of Mrs. Moor as a tolerant, God revering Christian lady, who is implied to be majorly benevolent towards the natives and is dysphoric at the malicious intervention of the Indian people by the British Empire and its officials. A new aspect of imperium is showed by Fielding, the principal of Government College. The principal of Government College is not slaked with the big varies brought about by a few reassigns and postings. The British Empire can keep on only if its functionaries are sympathetic and authentically affable towards the natives. In reality justice ne'er gratifies them and the result is that the Brit Imperium 'rests on sand'. Sir Gilbert, The Lieutenant Governor has the newfangled discipline of thought towards the organization of the settlements. Forster is not an antagonist of Imperium, he only knows how to post new approach of empire on Indians as Sir Gilbert did. The European necessitate to uprise with a firm new approach to sustain their clench over India. Forster draws his new doctrine sparkler clear through Fielding. Throughout the history even $19^{\text {th }}$ century, when brutality and shabbiness ramped any empire, the hidden authority revived their harries as Foster's white characters try to repair British Empire. This is new approach to maintain dominancy over colonized.

\subsection{Emergence of the Indian Identity}

In reality, Indians have no identity in Foster's India; their identity is no more than locals, others, pigeonholes, stamps and deformed humans. Altho, colonized land is revealed tardily and steadily stirring towards its heredity and uniqueness, but it has not ensued in the expansion of state-run distinctiveness and confrontation against victimization of colonialism. There is no agreeable statement with Cronin, according to Cronin that Dr. Aziz turns into 'a nationalist hero', after his exoneration (1989). Actuality he is not able to present himself as a national hero. Singh (1975) rightly avers that Dr. Aziz is not a hero. Forster's cognizance of Anglo India demonstrates astuteness and incursion is amplification. It is only the propaganda to renew the old imperial approaches and the reiteration of the old Orientalist construction.

Foster's educated Indians live in the langsyne, plunged in suffering. They live far behind from present time. Foster shows that his most highly educated Indian, Dr. Aziz is as a sissy and not as a pugilist. He retires to an indigen land, which is showed as 'jungle state', instead of fighting against the Imperialism, against its coercion and iniquity.

Even the temple shows the malformed wallop of colonial traditions. The Hindoo euphony at the religious fêtes is associated by European euphony and bands. This is the portraiture of the wallop of colonial acculturation and the sequent loan-blend. In every part of Foster's "A Passage to India", Subcontinent is shown as a realm where the whole thing is benighted. Foster also foregrounds tattily 
the allotments in the Hindoo society. The soil of India is shown as a land of crevices. The Indian flagwavers, chauvinists and supporters of independence are presented as people who kvetch and yell on groups. Towards the end Dr. Aziz throws his ataraxis with the British. Dr. Aziz is a souvenir, a crown of the illicit squeeze between British Colonizer and the Colonized India. Dr. Aziz is totally dissimilar from Narayan's Sri Ram, who absolutely refuses imposing colonial acculturation. Crane names "A Passage to India" an affirmative narrative on the base of the development towards the association 'tween the Denizen Occidentals and the Indian Orientals. This divulges the restriction of Crane. $\mathrm{He}$ colligates hisself with the Colonizer, to amplify Neo Oriental approach of dominancy.

\section{CONCLUSION}

The bailiwick has proved that "A Passage to India", make strengthen the Imperialist thought of transcendency and Neo Oriental Philosophy. The work also shows its indispensable plan that " $A$ Passage to India" is an Imperialist intervention in which Indians have no status, they are pigeonholes and subhuman. After study of this work, we come to know that Said's Culture and Imperialism fits on "A Passage to India" because it shows how imperial powers change religious, social, cultural and moral values of colonized people to maintain their empire and Orientalist dominancy over colonized lands. Foster has not pictured any Indian jingoist or the revolt by the Indian people to eliminate their chains of slavery. Work shows how educated Indians wanted to make good relationship with Britain Raj through their flattery. The depiction of Indians as they hate their own culture and feel shyness to represent Indian culture because they think their way of life is not so good. The present study has revealed that this is the protrusion of the British predominant premisses. Foster wants to become an innocent that he is not interested to expand the colonial approach but my research unrobes him for his interest in empire. Through the characters of Sir Gilbert, Fielding and Mrs. Moor, Foster flings an unconventional approach. This work has revealed that "A Passage to India" is written in the overhaul of Empire.

Foster has proved at every step of the novel that British as master human race, superior executives and master of all human beings. The Indian people are introduced as credulous, timid, ridiculous absurd and edgy. The paper has evidenced its effronteries regarding the depiction of the Indian people as deformed human by Forster.

\section{REFERENCES}

Ali Behdad. (1994). Orientalism in the Age of Colonial Dissolution, Volume 244 of Chiviyazılart: Nemesis Kitaplı̆gl;19: Post-Contemporary Interventions. Duke University Press, ISBN: $0822314711,9780822314714$.

Benita Parry. (2004). Postcolonial Studies: A Materialist Critique, Benita Parry, Routledge, Cultural Critique 62 (2006) 207-209.

Bhabha, Homi, K. (2004). The Location of Culture, London: Routledge.

Boehmer, Elleke. Colonial and Postcolonial Literature: Migrant Metaphors. Oxford: Oxford UP, 1995.

Brandabur, Clare. (1993). "Images of women in five post-colonial novels", Aegean Journal of Language and Literature, proceedings of 13th All-Turkey English Literature Conference 1992 (special issue), Izmir.

Brenda R. Silver (2013). "Intellectual Crossings and Reception." Forthcoming in The Cambridge Companion to Bloomsbury, ed, Victoria Rosner. CambridgeUniversity Press.

Charles E. Allen. (2009). Keynote Address at GEOINT Conference by Under Secretary for Intelligence and Analysis /Chief Intelligence Officer," Department of Homeland Security, Release Date: October 28, 2008, accessed November 14, 2009.

Childs, Peter. (1999). Post-Colonial Theory and English Literature: A Reader. Edinburgh: Edinburgh University Press.

Crane, R. J. (1992). Inventing India: A History of India in English Language Fiction. Hounds Mill: Basingstoke Macmillan.

Cronin, R. (1998). Imagining India. London: The Macmillan Press.

Fanon, F. (2001). The Wretched of the Earth. Trans. Constance Farrington. London: Penguin Books. 
Fanon, F. (2008). Black Skin, White Masks. Trans. Charles Lam Markman. London: Pluto Press.

Forster, E. M. (1981). A Passage to India. London: Penguin.

Fowzia Afzal. (1993). Cultural Imperialism and the Indo-English Novel: Genre and Ideology in R. K. Narayan, Anita Desai, Kamala Markandaya, and Salman Rushdie. Copyright: 1993. ISBN: 9780-271-03295-5.

Ghose, Z. (1998). The Murder of Aziz Khan. Karachi: Oxford University Press.

Green, M. (1980). Dreams of Adventure, Deeds of Empire. London: Rutledge \& Kegan Paul.

Homi K. B. (1990). Sexual Subjects. New York: Routledge.

Kennedy, Valerie. (2000). Edward Said: A Critical Introduction, Cambridge: Polity Press.

Khan, F. A. (1993). Cultural Imperialism and the Indo-English Novel. Pennsylvania: The Pennsylvania State University Press.

Kincaid, J. (1988). A Small Place, London. London : Virago .

Masters, J. (1975). Bhowani Junction. New York: Harper.

Memmi, Albert. (1974). The Colonizer and The Colonized. 1965. rpt. London: Souvenir Press.

Narayan, R. K. (2000). Waiting for the Mahatma, London: Vintage.

Parry, B. (1985). A Passage to India:Essays in Interpretation. London.

Patrich Brantlinger. (2013). States of Emergency: Essays in Culture and Politics. Indiana University Press.

Penelope Pether. (1991). A transcending civilization : England and Englishness in the works of E.M. Forster and Virginia Woolf / [Penelope Jane Pether]. Thesis (PhD.)--University of Sydney, 1997.

Purabi Panwar. (2000). India In The Works Of Kipling, Forster And Naipaul: Postcolonial Revaluations.

Said, Edward W. (1983). The World, the Text and the Critic, Massachusetts: Harvard University Press.

Said, E. W. (1993). Culture and Imperialism. London: Vintage Book.

Said, E. W. (2001). Orientalism. New Delhi: Penguin Books.

Sidhwa, B. (1989). Ice Candy Man. New Delhi: Penguin Books.

Singh, B. (1975). A Survey of AngloIndian Fiction. London: Curzon Press Ltd.

Suleri, S. (2005). The Rhetoric of English India. New Delhi: Penguin Books.

Tambling, J. (1995). New Case Book Series.London: Macmillan.

Tradition and the Individual Talent. (1919). T. S. Eliot's Truman State University.

\section{AUTHOR'S BIOGRAPHY}

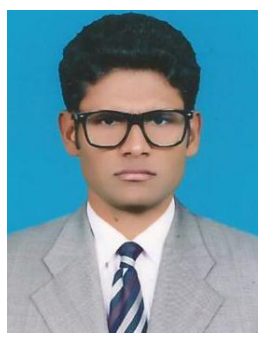

Muhammad Ehsan, has been a PhM Scholar in English Literature and has been Litterateur, learning the 'World Politics' through Literature. He holds a master degree at The Department of Humanities and Linguistics (University of Agriculture, Faisalabad. Pakistan), doing PhM at Department of English Language \& Literature, The University of Lahore, Pakistan. He has participated and attended many conferences. He has published many papers and also working on his oeuvre poetry, short stories and political ideas. 